\title{
Pengaruh Kolektor Pelat Gelombang Dengan Dua Kaca Penutup Terhadap Penambahan Panas Untuk Meningkatkan Kinerja Solar Water Heater
}

\author{
Dian kusuma $^{1}$, Mustafa ${ }^{2}$, Sudarno $^{3}$ \\ ${ }^{\text {I}}$ Fakultas Teknik, Universitas Merdeka Madiun, Jl. Serayu No. 79, Madiun, 63133 \\ E-mail: dheankusuma25@gmail.com \\ ${ }^{2}$ Fakultas Teknik, Universitas Merdeka Madiun, Jl. Serayu No. 79, Madiun, 63133 \\ E-mail: mustafa@unmer-madiun.ac.id \\ ${ }^{3}$ Fakultas Teknik, Universitas Merdeka Madiun, Jl. Serayu No. 79, Madiun, 63133 \\ E-mail: sudarno@unmer-madiun.ac.id
}

\begin{abstract}
The worked principle of solar collector wave absorber plate was to transfer solar radiation to the worked fluid. The solar radiation that falls on the first glass was partially reflected, then on the second glass partially absorbed by the absorbent plate. The heat absorbed by the absorbent plate will be used to heat the worked fluid (water) between the absorbent plate and the storage plate. The purpose of this research was to design and make solar collector used wave plate with two cover glass. The addition of incomed water heat used temperatures of $30{ }^{\circ} \mathrm{C}, 40{ }^{\circ} \mathrm{C}, 50^{\circ} \mathrm{C}$. The method used was used an expriment by analyzed the effect of initial heat addition on efficiency. From the results of test data obtained collector performance of solar water heater the greater the addition of heat used then the smaller the efficiency. Each of the average heat additions efficiency at $30{ }^{\circ} \mathrm{C}$ was $19.66 \%$, the temperature of $40^{\circ} \mathrm{C}$ was $17.75 \%$, and the temperature of $50{ }^{\circ} \mathrm{C}$ was $12.23 \%$.
\end{abstract}

Keywords - : wave absorbent plate; added heat; solar water heater.

\section{PENDAHULUAN}

\section{A. Latar Belakang}

Energi radiasi dari matahari merupakan salah satu bentuk energi alternatif yang dapat dimanfaatkan untuk berbagai kepentingan guna meningkatkan energi yang dihasilkan oleh minyak bumi. Salah satu bentuk pemanfaatan dari energi radiasi matahari adalah untuk memanaskan air. Pemanfaatan energi surya untuk pemanas air dilakukan dengan cara mengumpulkan energi surya menggunakan panel kolektor berpenutup kaca yang didalamnya dilengkapi dengan pelat absor dan pipa air. Radiasi surya yang jatuh pada permukaan kaca akan diteruskan dan kemudian diserap oleh absorber. Panas dari absorber dimanfaatkan untuk memanaskan air yang mengalir dalam pipa. Air dengan temperatur tinggi ditampung dalam tanki penyimpan kemudian dimanfaatkan.

\section{B. Manfaat dari penelitian}

1. Dari hasil penelitian dapat mengetahui dalam perancangan dan pembuatan kolektor surya pelat gelombang dengan menggunakan dua kaca penutup.

2. Dapat digunakan untuk penelitian lebih lanjut dengan berbagai variasi sehingga efisiensi yang paling baik akan didapatkan.

3. Dapat digunakan sebagai salah satu pemanfaatan sumber energi yang ramah lingkungan dan tidak akan habis.

4. Dapat dikembangkan menjadi teknologi yang aplikatif bagi manusia.

\section{Batasan Masalah}

1. Proses pengujian menggunakan kolektor solar water heater pelat gelombang dengan dua kaca penutup.

2. Penambahan panas ditentukan dengan menggunakan alat pemanas sebagai pengendali heater sebesar $30{ }^{\circ} \mathrm{C}, 40{ }^{\circ} \mathrm{C}, 50{ }^{\circ} \mathrm{C}$.

3. Hasil pengukuran tiap interval waktu setiap 15 menit.

4. Kapasitas fluida yang ditetapkan sebesar 20 litre.

5. Laju aliran fluida yang ditetapkan sebesar 0,011 litre/detik.

6. Posisi kemiringan kolektor sebesar $15^{\circ}$ tanpa merubah posisi arah sinar matahari.

7. Volume fluida didalam kolektor sebanyak $14.700 \mathrm{~cm}^{3}$. 


\section{TINJAUAN PUSTAKA}

\section{A. Penelitian terdahulu}

Menurut Subur Edi Sudrajat dan Irfan Santoso, 2014 pada Nurhalim, 2011 Salah satu alternatif untuk memenuhi air panas adalah dengan menggunakan media surya sebagai supplay energinya. Untuk meningkatkan efektifitas pemanfaatan energi surya secara langsung, dapat dikembangkan dengan menggunakan pengumpul - pengumpul panas yang bisa disebut kolektor, salah satunya adalah kolektor pemanas air.

Menurut Maftukhil Murot dkk., 2016, pada Rico A. dkk., 2012 juga melakukan penelitian untuk meningkatkan kinerja dinding sebagai pelat penyerap, dinding dibuat bergelombang. Penelitian dengan judul penambahan volume dinding bergelombang sebagai alat penyerap pada solar water heater adalah berpengaruhnya temperatur air apabila laju aliranya melambat, laju aliran yang melambat juga dapat membuat pelat penyerap menjadi lebih optimal dalam melakukan penyerapan panas sehingga frekuensi terbuangnya panas dapat diperkecil.

Menurut Maftukhil Murot dkk., 2016, pada Arif dkk., 2013 meneliti tentang bentuk dan luasan pelat penyerap pada solar water heater sederhana yang menghasilkan bentuk segitiga dan dengan bentuk segitiga yang lebih kecil lebih meningkatkan efisiensi solar water heater sederhana.

Kolektor surya tersusun dari pelat penyerap yang mempunyai konduktivitas termal yang baik. Permukaannya bisa pelat bergelombang atau datar. Selain pelat penyerap, kolektor surya juga tersusun atas isolator dan satu atau lebih penutup tembus cahaya pada bagian atasnya biasanya digunakan adalah kaca. Dari penelitian kolektor pelat datar sebelumnya bahwa jenis kaca yang paling tepat digunakan adalah kaca bening dengan tebal 3 mm (Anggraini, Ekadewi H., 2002).

Secara umum dapat dikatakan bahwa penggunaan kolektor dengan dua buah kaca penutup adalah lebih baik dari pada hanya menggunakan sebuah kaca penutup saja. Perbedaan suhu yang dicapai dengan percobaan dengan dua kaca penutup untuk intensitas cahaya total antara 477 hingga 711 watt $/ \mathrm{m}^{2}$ adalah $25{ }^{\circ} \mathrm{C}$ hingga $42{ }^{\circ} \mathrm{C}$ sedangkan kolektor dengan sebuah kaca penutup yang menerima intensitas cahaya mulai dari 419 hingga 741 watt $/ \mathrm{m}^{2}$ hanya memiliki perbedaan suhu antara $15{ }^{\circ} \mathrm{C}$ hingga $28^{\circ} \mathrm{C}$ saja. Secara umum dapat dikatakan pula bahwa penggunaan kolektor dengan dua buah kaca penutup adalah lebih efektif pada intensitas cahaya yang relatif tinggi, dalam percobaan diatas $600 \mathrm{watt} / \mathrm{m}^{2}$ (Rahardjo T., Anggraini, Ekadewi H., 1999).

Menurut Maftukhil Murot, dkk., 2016 pada Rahardjo Tirtoatmodjo, 2005 bahwa Menggunakan dua buah kaca penutup diperoleh efisiensi yang lebih baik dibandingkan hanya menggunakan satu kaca. Perbedaan suhu antara air keluar kolektor dan yang masuk ke kolektor dengan 2 kaca penutup bisa lebih tinggi hingga sekitar $17^{\circ} \mathrm{C}$ dibandingkan kolektor dengan sebuah kaca penutup.

Menurut Maftukhil Murot, dkk., 2016 pada Ismail dan Putra, 2005 bahwa kecepatan aliran air pada solar heater semakin cepat aliran maka air hangat yang dihasilkan memiliki temperatur semakin rendah dan pada pemanas air tenaga surya tipe kolektor pelat datar dengan kemiringan sudut $0^{\circ}$ menghasilkan temperatur air yang paling optimum yaitu dengan temperatur rata - rata $59,375^{\circ} \mathrm{C}$ dan suhu maksimum sebesar $71^{\circ} \mathrm{C}$.

Menurut Maftukhil Murot, dkk., 2016 pada Arif dkk., 2013 meneliti tentang bentuk dan luasan pelat penyerap solar water heater terbaik dapat dilihat dari temperatur dan efisiensi. Pada bentuk pelat maka pelat penyerap yang terbaik adalah pelat berbentuk segitiga sama kaki dengan temperatur sebesar $48,6^{\circ} \mathrm{C}$ dan pelat siku - siku memiliki temperatur $47,70^{\circ} \mathrm{C}$ dengan laju aliran $300 \mathrm{ml} / \mathrm{menit}$. Pelat segitiga siku-siku memiliki efisiensi terbaik sebesar $89,1 \%$ dan pelat segitiga sama kaki sebesar $71,2 \%$ dengan laju aliran $500 \mathrm{ml} / \mathrm{menit}$. Pada luasan $0,35 \mathrm{~m}^{2}$. Yaitu pelat segitiga sama kaki kecil memiliki temperatur sebesar $47,6^{\circ} \mathrm{C}$ dan pelat segitiga sama kaki sebesar dengan luasan permukaan $0,25 \mathrm{~m}^{2}$ memiliki temperatur $37,3^{\circ} \mathrm{C}$ dengan laju aliran $300 \mathrm{ml} / \mathrm{menit}$. Efisiensi yang dimiliki pelat segitiga sama kaki sebesar 86,7\% lebih baik dari pada pelat segitiga sama kaki kecil sebesar 60,1\% dengan laju aliran $500 \mathrm{ml} / \mathrm{menit}$.

Studi eksperimen sistem kolektor pelat ganda pada solar water heater. Penelitian menghasilkan efisiensi penyerap panas pada solar heater pelat ganda lebih tinggi dibandingkan efisiensi penyerap panas solar heater konvensional pada penambahan pemanasan awal dengan laju aliran air yang berfluktuasi maupun laju aliran yang berbeda, namun kontinyu dan hubungan antara efisiensi penyerap panas dan (Ti-Ta)/Gt pada solar heater pelat ganda penurunannya lebih tajam dibandingkan solar heater konvensional (Mustofa, 2008).

\section{B. Menetukan efisiensi}

Efisiensi panel kolektor adalah rasio antara tingkat panas yang berguna (QU) ditransfer ke cairan yang dibagi oleh matahari radiasi di pelat penutup Efisiensi dapat ditunjukkan di persamaan Duffie JA dan Beckman W.A. (1980), sebagai berikut:

$$
\eta=\frac{q_{u}}{A_{c} G_{T}}
$$

Dari persamaan diatas juga bisa menggunakan persamaan efisiensi kolektor sebagai berikut :

$$
\begin{gathered}
\eta=F_{R}(\tau \alpha)-F_{R} U_{L} \frac{(T i-T a)}{G_{T}} \\
\eta=\frac{\dot{m} C_{p}\left(T_{0}-T_{i}\right)}{G_{t} \cdot A_{c}}
\end{gathered}
$$


Hubungan efisiensi dalam grafik bisa ditulis sebagai berikut :

$(\mathrm{Ti}-\mathrm{Ta} / \mathrm{Gt})$

Keterangan :

$\mathrm{Qu} \quad=$ Energi yang diserap oleh

kolektor, $\left(\mathrm{W} / \mathrm{m}^{2}\right)$

Ac $\quad=$ Ukuran kolektor $\left(\mathrm{m}^{2}\right)$

FR = Faktor kehilangan panas kolektor

$\mathrm{UL} \quad=$ Kerugian panas keseluruhan $\left(\mathrm{W} / \mathrm{m}^{2}{ }^{\circ} \mathrm{C}\right)$

Gt $\quad=$ Total intensitas radiasi matahari $\left(\mathrm{W} / \mathrm{m}^{2}\right)$

$\mathrm{T}_{\mathrm{a}} \quad=$ Suhu lingkungan $\left({ }^{\circ} \mathrm{C}\right)$

$\mathrm{T}_{\mathrm{in}} \quad=$ Suhu air yang masuk $\left({ }^{\circ} \mathrm{C}\right)$

$\mathrm{T}_{\text {out }} \quad=$ Suhu air keluar $\left({ }^{\circ} \mathrm{C}\right)$

$\mathrm{C}_{\mathrm{p}} \quad=$ sifat air/cair jenuh $\left(\mathrm{kJ} /\left(\mathrm{kg} .{ }^{\circ} \mathrm{C}\right)\right)$

$\tau \quad=$ Kaca penutup transmisivitas

$\alpha \quad=$ Absorptivitas pelat penyerap

$\dot{m} \quad=$ Massa fluida $(\mathrm{kg})$

\section{Laju aliran massa fluida}

Merupakan jumlah massa fluida yang mengalir tiap satuan waktu dan dapat dinyatakan sebagai berikut :

$\dot{m} \quad=\frac{m}{t_{u}}=\frac{V \rho}{t_{u}}$

Keterangan :

$\dot{m} \quad=$ Massa fluida $(\mathrm{kg})$

$t_{u} \quad=$ Waktu pergerakan fluida dari ujung satu ke ujung yang lain dari kolektor panas surya (s)

$V \rho \quad=$ Volume fluida yang mengalir dari ujung satu ke ujung lain dari kolektor panas surya $\left(\mathrm{m}^{3}\right)$

\section{III.METODE PENELITIAN}

\section{A. Waktu dan Tempat}

Pelaksanaan penelitian dimulai dari pukul 10:00 WIB sampai dengan pukul 14:00 WIB pada tanggal 13, 14 dan 15 bulan November 2017 hingga selesai. Pengujian penambahan panas dan kinerja solar water heater dilakukan di halaman Teknik Mesin Universitas Merdeka Madiun Jl. Serayu Tromol Pos No.79 Pandean, Taman Kota Madiun.

\section{B. Alat dan Bahan}

Dari pengujian membutuhkan alat dan bahan sebagai berikut :

- Isolator tebal $=3 \mathrm{~cm}$

- $\quad$ Tanki air $=50$ liter

- Pipa sirkulasi $\varnothing=25,4 \mathrm{~mm}$

- Pompa

- Pelat penyerap seng tebal $=3 \mathrm{~mm}$

- Pelat penyimpan PVC $=10 \mathrm{~mm}$

- Kaca tebal $=5 \mathrm{~mm}$

- Selang air

- Stop kran = 1/2"

- Kerangka kolektor besi siku

- Precision Pyranometer

- Komputer/laptop

- Heater (pemanas air)

- Programable Periperal Interface (Ppi)

- Analog Digital Converter (ADC)

- Gelas pengukur

- Kabel roll

- Stop watch

- Alat ukur temperatur (LM 35) 


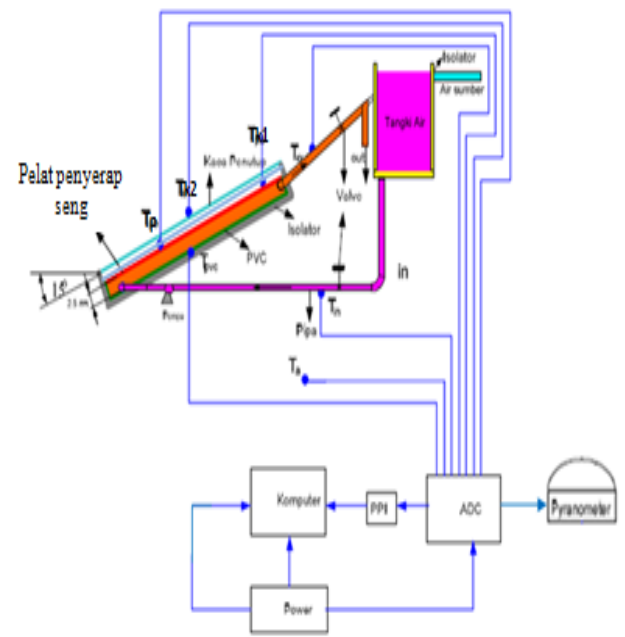

Gambar 1. Skema alat uji pemanas air tenaga surya (Mustofa, Ismail N. R., 2013)

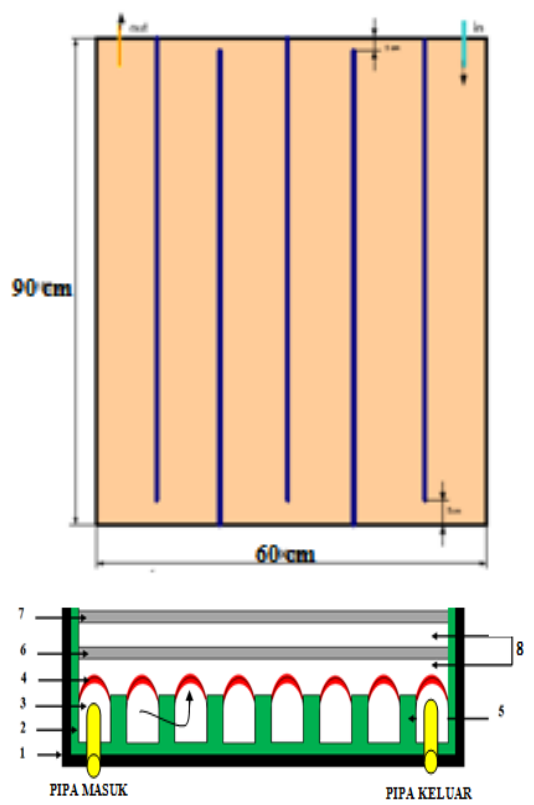

Gambar 2. Skema alat penyerap kolektor dengan alur zig zag

\section{Teknik Analisa Data}

Pada proses analisa data kita akan menguji efisiensi dari kolektor panas surya pelat gelombang dengan dua kaca penutup dan penambahan panas dengan memanfaatkan kinerja solar water heater. Mengetahui hubungan intensitas radiasi terhadap temperatur. Dengan menvariasikan penambahan panas menggunakan heater yang ditentukan sebesar $30^{\circ}, 40^{\circ}$ dan $50^{\circ}$, maka akan diketahui efisiensi pertambahan panas yang terbaik dan kinerja solar water heater pada kolektor, dan juga kemiringan kaca kolektor diketahui dengan jarak sudut $15^{\circ}$ tanpa merubah arah posisi sinar matahari. Pengujian solar water heater dilakukan mulai jam 10:00 - 14:00 WIB. 


\section{Prosedur Penelitian}

Langkah - langkah yang dilakukan dalam penelitian kinerja solar water heater ini adalah :



\section{IV.HASIL DAN PEMBAHASAN}

Dari hasil penelitian diperoleh data dan dapat dibuat grafik sebagai berikut :

\section{A. Grafik temperatur dan radiasi matahari}

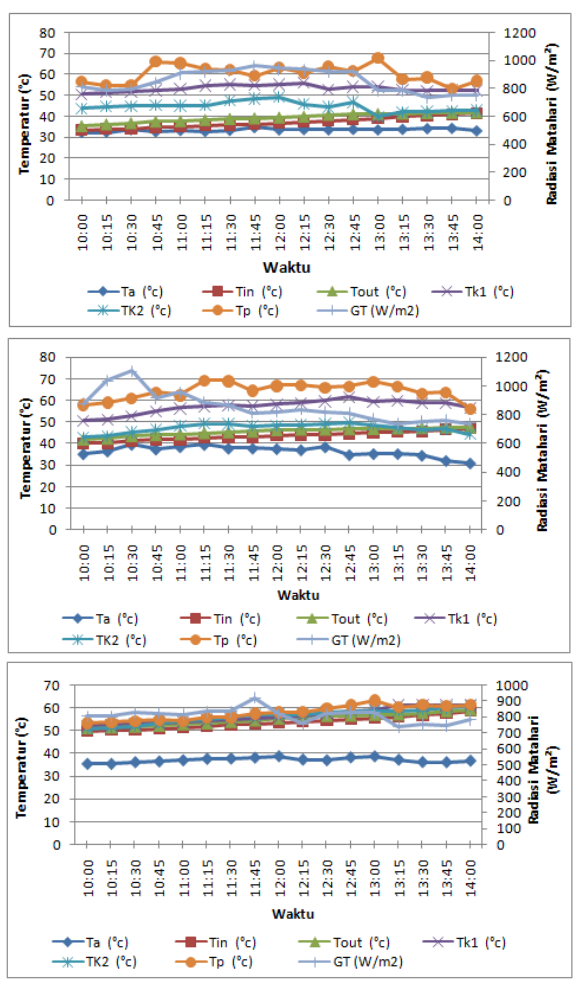

Gambar 3. Hasil pengujian pada temperatur $30^{\circ} \mathrm{C}, 40^{\circ} \mathrm{C}$ dan $50^{\circ} \mathrm{C}$. 
Dari grafik yang didapat intensitas radiasi matahari yang dihasilkan tidak berpengaruh terlalu besar dikarenakan adanya pertambahan panas sebesar $30{ }^{\circ} \mathrm{C}, 40^{\circ} \mathrm{C}$ dan $50{ }^{\circ} \mathrm{C}$ panas rata- rata yang dihasilkan mulai dari temperatur masuk sampai temperatur keluar

\section{B. Grafik hubungan temperatur rata-rata dengan intensitas radiasi matahari}

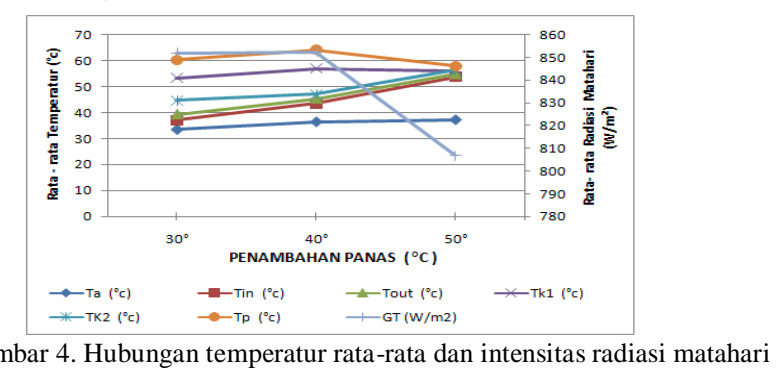

Data yang di ambil dimulai dari jam 10.00 sampai dengan pukul 14.00 dari total yang didapatkan dan hasilnya dirata - rata akan memperoleh hasil sesuai grafik yang tertera pada grafik gambar 4.4. Kondisi ini disebabkan karena saat pemanasan awal dimulai dari bak penampungan tanki sudah mengawali kenaikan temperatur air tentunya akan mengakibatkan kenaikan temperatur air di dalam sistem alat kolektor tersebut. Maka pengaruh yang terjadi bisa terlihat didalam temperatur pelat penyerap yang didapat dengan intensitas radiasi matahari yang diserap semakin besar dan temperatur yang diserap semakin besar juga. Maka dari itu sudah terlihat temperatur masuk dan temperatur keluar akan mengalai perbedaan temperatur.

\section{Grafik menentukan efisiensi}

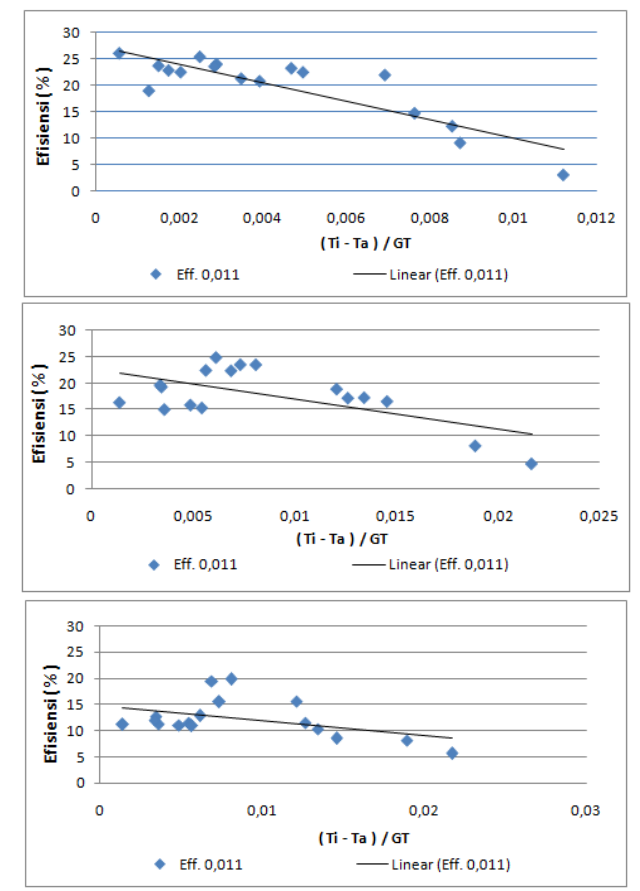

Gambar 5. Grafik hasil pengujian hubungan antara efisiensi dan (Ti-Ta/Gt) pada temperatur $30^{\circ} \mathrm{C}, 40^{\circ} \mathrm{C}$ dan $\quad 50{ }^{\circ} \mathrm{C}$.

Untuk menentukan hubungan antara efisiensi dan [ ( $\mathrm{Ti}-\mathrm{Ta}) / \mathrm{GT}]$ maka dapat disimpulkan bahwa efisiensi yang dihasilkan dari pengujian pertama yang didapat sampai dengan pengujian terakhir mengalami penurunan yang dimaksud bahwa efisiensi pemanasan air surya mendekati nol / stagnasi diakibatkan karena suhu temperatur masuk dan keluar mengalami kesamaan seiring saat pengujian 


\section{Grafik hubungan antara ke tiga efisiensi dengan (Ti-Ta/Gt)}

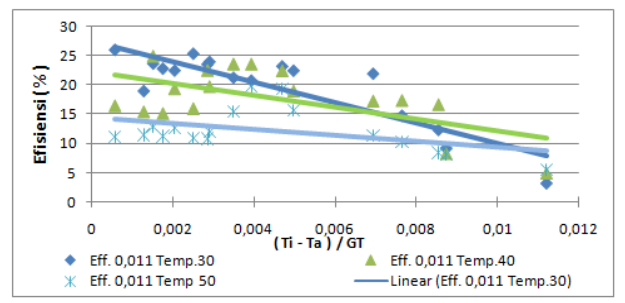

Gambar 6. Grafik hubungan antara ke tiga efisiensi dengan (Ti-Ta/Gt)

Pada grafik pengujian diatas dapat disimpulkan bahwa pada ke tiga pertambahan panas yang dihasilkan pada temperatur 30 ${ }^{\circ} \mathrm{C}, 40{ }^{\circ} \mathrm{C}$ dan $\quad 50{ }^{\circ} \mathrm{C}$ pada laju aliran yang sama sebesar 0,011 liter/detik. Maka hubungan antara efisiensi dan $\left[(\mathrm{Ti}-\mathrm{Ta}) / \mathrm{G}_{\mathrm{t}}\right]$ mendapatkan grafik yang menunjukkan bahwa temperatur air sangat mempengaruhi efisiensi solar water heater dan temperatur air masuk semakin besar maka efisiensi radiasi matahari akan mendekati nol / stagnasi, dengan temperatur air masuk dan keluar akan mendapatkan hasil yang relatif sama. Dari ketiga pengujian mendapatkan hasil yang menunjukkan bahwa pengujian menggunakan penambahan panas didapat effisiensi yang terbaik pada pertambahan panas $30{ }^{\circ} \mathrm{C}$ dikarenakan semakin panas pertambahan panas yang digunakan pada awal pengujian maka temperatur yang digunakan tidak efektif dengan panas intensitas radiasi yang didapat.

\section{KESIMPULAN DAN SARAN}

\section{A. Kesimpulan}

Dari hasil penelitian, didapatkan kesimpulan sebagai berikut :

1. Perancangan di desain dengan sudut kemiringan $15^{\circ}$ tanpa merubah posisi arah sinar matahari. Pengaruh temperatur dari kaca yang digunakan mengalami perbedaan temperatur yang mana rata - rata temperatur pada kaca 1 sebesar $55,58{ }^{\circ} \mathrm{C}$ pada ketiga pengujian dan temperatur pada kaca 2 sebesar $49,42{ }^{\circ} \mathrm{C}$ pada ketiga pengujian, dikarenakan radiasi matahari yang dipantulkan pada kaca 2 tidak begitu besar dibandingkan pada kaca 1 disebabkan oleh pengaruh udara lingkungan. Dan pada temperatur kaca 1 mengalami panas yang lebih diakibatkan oleh radiasi yang diteruskan pada kaca 2, sehingga keuntungan menggunakan 2 kaca penutup berpengaruh pada pelat penyerap untuk menambah panas dari intensitas radiasi matahari.

2. Pengaruh temperatur bergantung pada penambahan panas, intensitas radiasi, temperatur masuk, dan temperatur keluar. Dengan hasil terbaik pada temperatur $30{ }^{\circ} \mathrm{C}$ untuk intensitas radiasi matahari sebesar $851,9 \mathrm{~W} / \mathrm{m}^{2}$ temperatur masuk sebesar $37,1^{\circ} \mathrm{C}$ dan temperatur keluar sebesar $39,3{ }^{\circ} \mathrm{C}$. Semakin besar penambahan panas yang digunakan maka semakin kecil efisiensi yang didapat. Dengan hasil efisiensi panas terbaik pada temperatur $30^{\circ} \mathrm{C}$ panas yang didapat pada awal pengujian sebesar $18,87^{\circ} \mathrm{C}$ mengalami penurunan sangat tajam dengan temperatur akhir sebesar $3,10{ }^{\circ} \mathrm{C}$ dengan rata - rata efisiensi yang didapat sebesar $19,66^{\circ} \mathrm{C}$.

\section{B. Saran}

Dari hasil penelitian, didapatkan Saran sebagai berikut :

1. Penelitian dapat dilanjutkan dengan cara penambahan menggunakan tracker / pergeseran sudut kolektor terhadap radiasi matahari.

2. Penelitian dapat dilanjutkan dengan cara merubah sistem kerja menggunakan motor penggerak otomatis sehingga data yang di hasilkan lebih akurat.

Jika ingin didapatkan laju aliran yang maksimal setiap sudut yang dilewati fluida air diberi sudut radius sehingga laju aliran yang dihasilkan lebih bisa loss.

\section{VI.DAFTAR PUSTAKA}

Anonim, 2017: wibe site: unmermadiun.ac.id, tanggal 26 Agustus 2017

Anonim. Bab II Landasan Teori Prinsip Kerja Kolektor surya Pelat Penyerap. 809b5f3ff5dc603fbc474afe006faef2,Tanggal 16 Mei 2017.

Anggraini, Ekadewi Handoyo, 2002: Jurnal Teknik Mesin Universitas PETRA, Surabaya.

Arismunandar, W. 1995. Teknologi Rekayasa Surya. edisi pertama. PT Pradnya Paramita. Jakarta.

Burhanuddin, A. 2006. Karakteristik kolektor surya pelat datar dengan variasi jarak kaca penutup dan sudut kemiringan kolektor. Skripsi. Fakultas Matematika dan Ilmu Pengetahuan Alam Universitas Sebelas Maret, Surakarta.

Beizer, 1981, Konsep Fisika Modern. Jilid 3. Terjemahan The Houw Liong Ph.D, Penerbit Erlangga, Jakarta.

Culp, 1991, Prinsip-prinsip Konversi Energi, Penerbit Erlangga, Jakarta.

Duffie, dan Beckman. , 1991: Solar Engineering of Thermal Processes, John Willey and Sons Inc, Wisconsin.

Giancoli, 1998: Fisika edisi kelima (Terjemahan Yuhilza Hanum), Erlangga, Jakarta.

Jasjfi, 1995: Perpindahan kalor, Erlangga, Jakarta.

Lunde, 1980, jbptitbpp-gdl-rahadianef-30837-2008ta-2.pdf, Bab II, Teori dasar 8.

Maftukhil Murot, dkk., 2016. Pengaruh Penambahan Tekanan Diatas Pelat Penyerap Terhadap Kinerja Solar Water Heater Sederhana, Widya Teknika, Vol. 24, N0. 2: 20-32.

Mustofa, 2008, Studi Eksperimen Pengaruh pelat penyerap ganda model gelombang dengan penambahan reflektor terhadap kinerja Solar Water Heater sederhana, Dosen Teknik Mesin, Universitas Merdeka Madiun.

Mustofa, Ismail N. R., 2013, International Jurnal of Research in Engineering and Technologi, volume.02, Issue.09, September 2013. 
Website : http://pilar.unmermadiun.ac.id/index.php/pilarteknologi

Prijono, 1986, Prinsip-prinsip Perpindahan Panas, Penerbit Erlangga, Jakarta.

Rahadian, 2008 : Jurnal Teknik Mesin Universitas Sumatra Utara.

Sijabat, Andri M. 2014. Rancang Bangun dan Analisa Kolektor Surya Tipe Pelat Datar Bersirip Untuk Penghasil Panas Pada Pengering Hasil Pertanian dan Perkebunan. Skripsi. Fakultas Teknik Universitas Sumatra Utara, Medan.

Subur Edi S., Irfan Santoso. 2014. Jurnal Teknologi: Perancangan Solar Water Heater Jenis Pelat Datar Temperatur Medium Untuk Aplikasi Penghangat Air Mandi. Volume 7 Nomor 2: 118-127.

Tirtoatmodjo, R., Ekadewi, A. H, 1999: Jurnal Teknik Mesin Universitas Kristen Petra. 